\title{
International Agreement on Tropical Timber Adopted
}

The United Nations Conference on Tropical Timber, which held two sessions in 1983 under UNCTAD (United Nations Conference on Trade and Development) auspices, successfully concluded its work on 18 November by adopting the International Tropical Timber Agreement 1983. The objectives of the Agreement are to provide an effective framework for cooperation and consultation between tropical timber-producing and -consuming countries with a view to promoting the expansion and diversification of international trade in tropical timber and improving structural conditions in the tropical timber market.

To these ends the Agreement seeks to promote research and development aimed at improving forest management and wood utilization; to improve market intelligence; to encourage increased and further processing of tropical timber in producing member countries; to encourage reafforestation and forest management activities; to improve marketing and distribution of tropical timber exports of producing members; and to encourage national policies aimed at sustainable utilization and conservation of tropical forests together with their genetic resources while always maintaining the ecological balance in the regions concerned. It is envisaged that projects in these areas will be financed from the Second Account of the Common Fund for Commodities when it becomes operational, from regional and international financial institutions, and from voluntary contributions.

For the purposes of the Agreement 'tropical timber' is defined as non-coniferous tropical wood for industrial uses, which grows or is produced in the countries situated between the Tropic of Cancer and the Tropic of Capricorn. The term covers logs, sawnwood, veneer sheets, and plywood. Following the adoption of the Agreement, the Chairman, Tatsuro Kunugi (Japan), said that the Asian producing members had indicated their intention to pursue the question of a wider definition of tropical timber products with the International Tropical Timber Council, which will be the highest authority of the
International Tropical Timber Organization that is to be established under the Agreement.

In the Council, half of the votes will be held by producing countries and half by consuming countries. Within each of these groups, votes will be distributed among individual countries according to certain formulae related to their interest in tropical timber. Projects for financing or sponsorship will be approved by the Council by special vote, which means a vote requiring at least twothirds of the votes cast by producing members present and voting, and at least $60 \%$ of the votes of consumer members present and voting, counted separately, on condition that these votes are cast by at least half of the producing member countries and at least half of the consuming member countries present and voting.

Following the adoption of the Agreement, the representative of the United States, Clinton Shaw, said that his delegation was reserving its position on the provisions concerning the distribution of votes and the definition of the special vote. One of the first tasks of the Council will be to decide on the location of the headquarters of the Organization. The countries which have so far offered to provide sites are Belgium, France, Greece, Indonesia, Japan, Netherlands, and the United Kingdom.

The Agreement is being held open for signature at United Nations Headquarters, New York, from 2 January 1984. It will enter into force definitively on 1 October 1984, or on any date thereafter, provided that not fewer than 12 governments of producing countries holding at least $55 \%$ of the total votes and 16 governments of consuming countries holding at least $70 \%$ of the total votes, have signed the Agreement definitively or have ratified it.
INFORMATION UNIT OF UNCTAD
United Nations Conference on Trade \& Development
Palais des Nations
1211 Geneva 10
Switzerland.

\section{ICSU/SCOPE Review of Environmental Consequences of Nuclear War}

The International Council of Scientific Unions (ICSU), through its Scientific Committee on Problems of the Environment (SCOPE), has under way a careful survey of the state of scientific knowledge concerning the expectable environmental consequences of possible nuclear war. The aim is to develop, among the world scientific community, a consensus on this most horrendous matter, and to make the findings available to fellow-scientists, to policy-makers, and to representatives of concerned citizen groups as well as Governments throughout the world.

The effort was authorized by the ICSU General Assembly in 1982, on the basis of a recommendation from the Fifth General Assembly of SCOPE, which had been held in June of that year in Ottawa, Canada* It is examining the full range of possible effects of nuclear war, including: production of dust, soot, and smoke; attenuation of ultraviolet radiation and stratospheric ozone; changes in weather patterns; electromagnetic pulses; direct and delayed radioactive fallout; and the

\footnotetext{
* Described in our Autumn issue of that year (Environmental Conservation, 9(3), pp. 263-4, 1982).-Ed.
}

consequences of such changes for water, soil, plants, humans, and other animals.

The Review is enlisting the collaboration of leading scientists from more than 12 countries, and is drawing upon the information supplied in papers and conferences such as the Conference on the World After Nuclear War, which was held in Washington, DC, during 31 October-1 November $1983 .^{\dagger}$ A session to plan the ICSU/SCOPE Review was hosted by the Swedish Royal Academy of sciences in October 1983. The plans were carried further with special regard to agricultural effects at New Delhi in February 1984. Under the chairmanship of Sir Frederick Warner, of the United Kingdom, the Review has a Steering Committee with other members from France, India, Japan, the Netherlands, Sweden, the USA, and the USSR, and including a representative from ICSU's Executive Board.

It is expected that a workshop on atmospheric aspects will be held in Leningrad fairly early in 1984, and that another,

\footnotetext{
$\dagger$ See, inter alia, the account by Dr Norman Myers published on pp. 79-80 of our latest issue.-Ed.
} 